\title{
FAKTOR YANG MEMPENGARUHI PROFITABILITAS PADA PERUSAHAAN PROPERTY DAN REAL ESTATE YANG TERDAFTAR DI BEI PERIODE 2012-2015
}

\section{Hantono}

Universitas Prima Indonesia

A R T I C LE IN F O

Keywords :
Turnover Turnover Cash, Receivables, Liquidity,
Profitability

Kata Kunci : Perputaran Kas, Perputaran Piutang, Likuiditas, Profitabilitas

Corresponding author :

Hantono

hantono_78@yahoo.com
Abstrack: The purpose of this research was to prove there is whether or not the influence of rotation of cash, accounts receivable turnover, liquidity and profitability of the company against property and real estate in BEI. The population in this research is the entire company property and real estate by taking the sample criteria amounted to 50 company property and real estate. Engineering data collection using the library and documentation studies through the medium of the internet site www.idx.co.id. The research on analysis techniques using multiple linear regression, $t$ test and F-test.

Abstrak : Tujuan penelitian ini adalah untuk membuktikan ada tidaknya pengaruh perputaran kas, perputaran piutang, dan likuiditas terhadap profitabilitas pada perusahaan property dan real estate di BEI. Populasi dalam penelitian ini adalah seluruh perusahaan property dan real estate dengan mengambil kriteria sampel berjumlah 50 perusahaan property dan real estate. Teknik pengumpulan data menggunakan studi pustaka dan dokumentasi melalui media internet dengan situs www.idx.co.id. Teknik analisis pada penelitian ini menggunakan regresi linear berganda, uji F dan uji t. 


\section{PENDAHULUAN}

\section{Latar Belakang Masalah}

Kemajuan dan perkembangan kegiatan suatu perusahaan memberikan pengaruh positif terhadap kenaikan harta perusahaan. Pada umumnya tujuan perusahaan adalah memperoleh laba yang maksimal dan terus-menerus. Untuk mencapai tujuan tersebut maka semua kegiatan perusahaan harus dijalankan dengan sebaik-baiknya dan seefisien mungkin.

Profitabilitas perusahaan selalu menjadi perhatian utama bagi para pemilik perusahaan, manajemen perusahaan, investor atau calon kreditur. Profitabilitas menggambarkan kemampuan perusahaan mendapatkan laba melalui semua kemampuan dan sumber yang ada. Bagi perusahaan masalah profitabilitas sangatlah penting. Bagi pimpinan perusahaan, profitabilitas digunakan sebagai tolak ukur berhasil atau tidaknya perusahaan yang dipimpinnya, sedangkan bagi karyawan perusahaan semakin tinggi profitabilitas yang diperoleh oleh perusahaan maka ada peluang untuk meningkatkan gaji karyawan.

Profitabilitas perusahaan diharapkan dapat meningkat setiap periodenya dengan melihat beberapa elemen keuangan pada perusahaan. Salah satunya adalah melalui kas. Agar dapat mencapai kas yang stabil maka perusahaan perlu melakukan pengaturan terhadap pengeluaran dan penerimaan. Kas yang stabil akan berpengaruh terhadap meningkatnya laba pada perusahaan. Tingkat perputaran kas menggambarkan kecepatan arus kas kembalinya kas yang telah ditanamkan di dalam modal kerja. Menilai ketersediaan kas dapat dihitung dari perputaran kas.

Perputaran kas yang cukup tinggi, pada sistem perdagangan dewasa ini lebih cenderung dengan menggunakan sistem kredit daripada tunai sehingga akan mempengaruhi volume penjualan perusahaan. Semakin besar volume penjualan barang atau jasa, maka laba yang dihasilkan oleh perusahaan juga akan semakin besar.

Berdasarkan uraian di atas, hal inilah yang membuat peneliti tertarik untuk melakukan penelitian dengan judul "Pengaruh Perputaran Kas, Perputaran Piutang, dan Likuiditas terhadap Profitabilitas pada Perusahaan Property dan Real Estate Yang Terdaftar di BEI periode 2012-2015".

\section{Tujuan Penelitian}

Tujuan dari penelitian ini adalah : "Untuk mengetahui bagaimana pengaruh Perputaran Kas, Perputaran Piutang, dan Likuiditas terhadap Profitabilitas pada Perusahaan Property dan Real Estate Yang Terdaftar di BEI periode 2012-2015”.

\section{TINJAUAN PUSTAKA}

I Putu Gede Narayana (2013) melakukan penelitian dengan judul "Pengaruh Perputaran Kas, Loan to Deposit Ratio, Tingkat Permodalan dan Leverage terhadap Profitabilitas Bank Perkreditan Rakyat (BPR) Se-Kota Denpasar periode 2009-2011". Hasil penelitiannya menunjukkan bahwa Secara Simultan Perputaran Kas, Loan to Deposit Ratio, Tingkat Permodalan dan Leverage berpengaruh secara simultan terhadap Profitabilitas.Secara Parsial, Perputaran Kas, Loan to Deposit Ratio, dan Tingkat Permodalan berpengaruh secara parsial terhadap Profitabilitas, sedangkan Leverage tidak berpengaruh signifikan secara parsial terhadap Profitabilitas.

Luh Komang Suarnami, I Wayan Suwendra, Wayan Cipta (2014) melakukan penelitian dengan judul” Pengaruh Perputaran Piutang dan Periode Pengumpulan Piutang terhadap Profitabilitas pada Perusahaan Pembiayaan". Hasil penelitiannya menunjukkan bahwa secara simultan, Perputaran Piutang dan Periode Pengumpulan Piutang berpengaruh secara simultan terhadap Profitabilitas. Secara Parsial, Berdasarkan uji parsial, Perputaran Piutang berpengaruh positif tetapi tidak signifikan terhadap Profitabilitas, sedangkan Periode Pengumpulan Piutang berpengaruh positif dan signifikan secara langsung terhadap Profitabilitas.

\section{Kerangka Konseptual dan Hipotesis}

Berdasarkan latar belakang dan tinjauan teoritas yang telah dikemukakan sebelumnya, maka kerangka konseptual dapat digambarkan sebagai berikut : 


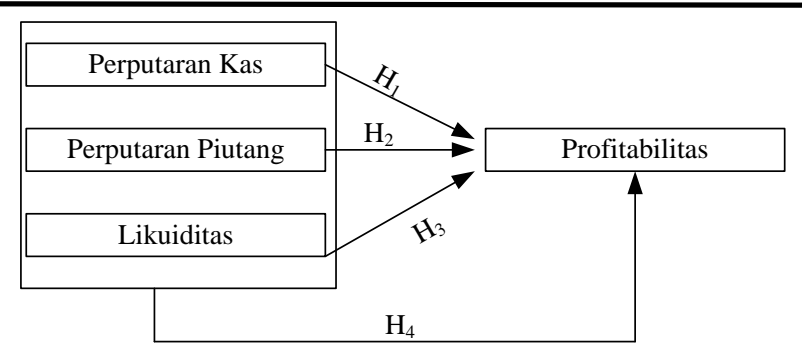

Gambar 1. Kerangka konseptual pengaruh profitabilitas

\section{Perputaran Kas}

Menurut Jumingan (2008:97), kas merupakan aktiva yang paling likuid atau merupakan salah satu unsur modal yang paling tinggi likuiditasnya.

Menurut Husnan (2012:107), kas merupakan bentuk aktiva yang paling likuid, yang bisa dipergunakan segera untuk memenuhi kewajiban financial perusahaan.

Menurut Munawir (2014:158), jumlah kas yang relatif kecil akan diperoleh tingkat perputaran kas yang tinggi dan keuntungan yang diperoleh akan lebih besar, tetapi suatu perusahaan yang hanya mengejar keuntungan (rentabilitas) tanpa memperhatikan likuiditas akhirnya perusahaan itu akan dalam keadaan likuid apabila sewaktuwaktu ada tagihan. Dapat disimpulkan kas sangat berperan dalam menentukan kelancaran kegiatan perusahaan.

Menurut Kasmir (2012:140), rumus yang digunakan untuk mencari rasio perputaran kas adalah sebagai berikut.

Rasio Perputaran Kas $=\frac{\text { Penjualan Bersih }}{\text { Modal Kerja Bersih }}$

\section{Pengaruh Perputaran Kas Terhadap Profitabilitas}

Menurut Jumingan (2008:97), jumlah kas yang relatif kecil akan diperoleh tingkat perputaran kas yang tinggi dan keuntungan yang diperoleh akan lebih besar.

Menurut Riyanto (2008:94), semakin besar kas maka berarti semakin banyaknya uang yang menganggur sehingga akan memperkecil profitabilitasnya.

Menurut Munawir (2014:158), jumlah kas yang relatif kecil akan diperoleh tingkat perputaran kas yang tinggi dan keuntungan yang diperoleh akan lebih besar.

\section{Perputaran Piutang}

Menurut Riyanto (2008:85), piutang (receivables) merupakan elemen modal kerja yang juga selalu dalam keadaan berputar secara terus menerus dalam rantai perputaran modal kerja.

Menurut Kasmir (2012:176), perputaran piutang merupakan rasio yang digunakan untuk mengukur berapa lama penagihan piutang selama satu periode atau berapa kali dana yang ditanam dalam piutang ini berputar dalam satu periode.

Semakin tinggi turnover-nya, berarti semakin cepat perputarannya, yang berarti semakin pendek waktu terikatnya modal piutang, sehingga untuk mempertahankan net credit sales tertentu, dengan naiknya turnover-nya, dibutuhkan jumlah modal yang lebih kecil yang diinvestasikan dalam piutang.

Menurut Kasmir (2012:176), cara mencari rasio ini adalah dengan membandingkan antara penjualan kredit dengan rata-rata piutang. Rumus untuk mencari receivable turn over adalah sebagai berikut.

Perputaran Piutang $=\frac{\text { Penjualan Kredit }}{\text { Piutang }}$

\section{Pengaruh Perputaran Piutang Terhadap Profitabilitas}

Menurut Riyanto (2008:86), semakin besar jumlah piutang berarti semakin besarnya resiko, tetapi bersamaan dengan itu juga memperbesar "profitability".

Menurut Sudana (2011:217), penjualan secara kredit menimbulkan biaya dan manfaat bagi perusahaan. Biaya yang timbul akibat penjualan kredit ada yang bersifat langsung seperti biava penagihan piutang dan biava tidak 3 
langsung berupa opportunity cost dari dana yang terikat dalam piutang. Sementara itu manfaat yang diperoleh perusahaan dari penjualan secara kredit adalah berupa peningkatan volume penjualan yang akan mengakibatkan peningkatan laba.

Menurut Sartono (2015:118-119), terlalu tinggi periode pengumpulan piutang itu berarti bahwa kebijakan kredit terlalu liberal atau bebas, akibatnya timbul bed-debt dan investasi dalam piutang menjadi terlalu besar akibatnya keuntungan akan menurun. Sebaliknya periode pengumpulan piutang yang terlalu pendek berarti kebijakan kredit terlalu ketat dan besar kemungkinannya perusahaan akan kehilangan untuk memperoleh keuntungan. Untuk itu standar kredit perlu diperlonggar.

\section{Likuiditas}

Menurut Sartono (2015:116), likuiditas perusahaan menunjukkan kemampuan untuk membayar kewajiban financial jangka pendek tepat pada waktunya. Likuiditas perusahaan ditunjukkan oleh besar kecilnya aktiva lancar yaitu aktiva yang mudah untuk diubah menjadi kas yang meliputi kas, surat berharga, piutang, persediaan.

Menurut Horne dan Wachowicz (2014:167), rasio likuiditas (liquidity ratio) mengukur kemampuan perusahaan untuk memenuhi liabilitas jangka pendeknya. Rasio ini membandingkan liabilitas jangka pendek dengan sumber daya jangka pendek (atau lancar) yang tersedia untuk memenuhi liabilitas tersebut. Dari rasio ini banyak pandangan ke dalam yang bisa didapatkan mengenai kompetensi keuangan perusahaan saat ini dan kemampuan perusahaan untuk tetap kompeten jika terjadi masalah.

Indikator likuiditas pada penelitian ini adalah current ratio. Menurut Kasmir (2012:134-135), rumus untuk mencari rasio lancar atau current ratio yang dapat digunakan sebagai berikut.

$$
\text { Current Ratio }=\frac{\text { Aktiva lancar (Current Assets) }}{\text { Utang lancar (Current Liabilities) }}
$$

\section{Pengaruh Likuiditas Terhadap Profitabilitas}

Menurut Sawir (2009:8), current ratio yang rendah biasanya dianggap menunjukkan terjadinya masalah dalam likuiditas. Sebaliknya suatu perusahaan yang current ratio-nya terlalu tinggi juga kurang bagus, karena menunjukkan banyaknya dana yang menganggur yang pada akhirnya dapat mengurangi kemampuan labaan perusahaan.

Menurut Syamsuddin (2011:209-210), pengukuran likuiditas yang paling sering digunakan adalah current ratio. Tingkat current ratio ditentukan dengan jalan membandingkan antara aktiva lancar dengan utang lancar. Apabila aktiva lancar meningkat maka profitabilitas maupun risiko yang dihadapi akan menurun. Sebaliknya, apabila aktiva lancar mengalami penurunan maka profitabilitas maupun resiko yang dihadapi akan meningkat. Sedangkan semakin meningkatnya utang lancar maka profitabilitas semakin meningkat. Sebaliknya, semakin menurunnya utang lancar maka profitabilitas juga akan semakin menurun.

Menurut Horne dan Wachowicz (2014:254), peningkatan likuiditas biasanya dibayar dengan penurunan profitabilitas.

\section{Profitabilitas}

Menurut Harahap (2015:304), rasio rentabilitas atau disebut juga profitabilitas menggambarkan kemampuan perusahaan mendapatkan laba melalui semua kemampuan, dan sumber yang ada seperti kegiatan penjualan, kas, modal, jumlah karyawan, jumlah cabang, dan sebagainya. Rasio yang menggambarkan kemampuan perusahaan menghasilkan laba disebut juga Operating Ratio.

Indikator dalam penelitian ini adalah ROA (Return on Assets). Menurut Keown, dkk (2008:89), rumus untuk hasil pengembalian atas total aktiva atau ROA (Return on Assets) :

$$
\text { ROA }=\frac{\text { Laba Bersih }}{\text { Total Aktiva }}
$$




\section{METODE PENELITIAN}

\section{Jenis Data}

Jenis data yang digunakan dalam penelitian ini adalah data sekunder, yaitu data yang tidak secara langsung diambil dari perusahaan ataupun data yang diperoleh dari pihak lain diluar perusahaan. Menurut Sugiyono (2012:376), data sekunder adalah sumber yang tidak langsung memberikan data kepada pengumpul data.

Data yang dipakai adalah data yang diambil dari website www.idx.co.id dan dari berbagai referensi yang berkaitan dengan data-data yang dipakai dalam penelitian ini.

\section{Pendekatan Penelitian}

Pendekatan penelitian ini dilakukan dengan penelitian kuantitatif. Menurut Sugiyono (2012:12), penelitian kuantitatif adalah penelitian yang berupa angka-angka dan analisis menggunakan statistik. Data yang diambil pada penelitian ini berupa data perputaran kas, perputaran piutang, arus kas operasi, likuiditas, dan profitabilitas pada perusahaan property dan real estate yang terdaftar di BEI periode 2012-2015.

Jenis penelitian yang digunakan adalah penelitian deskriptif. Menurut Sanusi (2012:13), desain penelitian deskriptif adalah desain penelitian yang disusun dalam rangka memberikan gambaran secara sistematis tentang informasi ilmiah yang berasal dari subjek atau objek penelitian. Penelitian deskriptif berfokus pada penjelasan sistematis tentang fakta yang diperoleh saat penelitian dilakukan.

Pada penelitian ini peneliti menggunakan sifat penelitian explanatory research. Menurut Effendi dan Tukiran (2012:5), explanatory research adalah sifat penelitian penjelasan data, yang menjelaskan hubungan kausal antar variabel (variabel dependen dan variabel independen) melalui proses pengujian hipotesis.

\section{Populasi dan Sampel}

Menurut Sugiyono (2012:115), populasi adalah wilayah generalisasi yang terdiri atas objek/subjek yang mempunyai kualitas dan karakteristik tertentu yang ditetapkan oleh peneliti untuk dipelajari dan kemudian ditarik kesimpulannya.

Pada penelitian ini peneliti akan menggunakan populasi pada perusahaan property dan real estate yang terdaftar di BEI periode 2012-2015.

Menurut Sugiyono (2012:116), sampel adalah bagian dari jumlah dan karakteristik yang dimiliki oleh populasi tersebut. Dalam penelitian ini peneliti menggunakan teknik purposive sampling. Menurut Sugiyono (2012:122), teknik purposive sampling yaitu teknik penentuan sampel dengan pertimbangan tertentu.

Teknik purposive sampling dilakukan dengan memilih populasi yang akan dijadikan sampel penelitian dan harus memenuhi kriteria-kriteria sampel tertentu sesuai dengan yang diinginkan peneliti dan dipilih berdasarkan pertimbangan tertentu disesuaikan dengan tujuan penelitian yang akan dicapai.

\section{Tabel 1. Kriteria dan Jumlah Sampel}

\begin{tabular}{llc}
\hline No. & \multicolumn{1}{c}{ Kriteria } & $\begin{array}{c}\text { Jumlah } \\
\text { Sampel }\end{array}$ \\
\hline 1. & $\begin{array}{l}\text { Perusahaan Property dan Real Estate yang terdaftar di } \\
\text { BEI selama periode 2012-2015. }\end{array}$ & 50 \\
2. & $\begin{array}{l}\text { Perusahaan Property dan Real Estate yang terdaftar di } \\
\text { BEI serta laporan keuangannya tidak dipublikasikan } \\
\text { secara berturut-turut selama periode 2012-2015. }\end{array}$ \\
3. & $\begin{array}{l}\text { Perusahaan Property dan Real Estate yang terdaftar di } \\
\text { BEI selama periode 2012-2015 yang tidak memperoleh } \\
\text { laba. }\end{array}$ & (12) \\
\hline
\end{tabular}

\section{Teknik Pengumpulan Data}

Teknik pengumpulan data yang digunakan dalam penelitian ini adalah studi pustaka dan dokumentasi. Menurut Sanusi (2012:32): 
a. Kepustakaan yakni pengumpulan data pendukung berupa literatur, penelitian terdahulu, dan buku - buku rujukan untuk mendapatkan gambaran dari masalah yang akan diteliti.

buku - buku teks merupakan sumber utama yang pada umumnya menjadi sasaran peneliti untuk memperoleh informasi ilmiah yang relevan dengan masalah penelitian. Buku - buku teks ini biasanya tersimpan di perpustakaan di lembaga pendidikan maupun lembaga - lembaga pemerintah dan lembaga bisnis.

b. Dokumentasi yaitu mengumpulkan data penelitian dengan menggunakan internet melalui situs www.idx.co.id untuk memperoleh laporan keuangan perusahaan Property dan Real Estate.

\section{Teknik Analisis Data}

Adapun langkah-langkah yang dilakukan oleh peneliti dalam menganalisa data adalah sebagai berikut :

\section{Uji Asumsi Klasik}

Uji asumsi ini digunakan untuk menguji apakah model regresi benar-benar menunjukkan hubungan yang signifikan dan representatif. Uji asumsi klasik dibagi menjadi empat tahap pengujian, yaitu uji normalitas, uji multikolinieritas, uji autokorelasi, dan uji heteroskedastisitas.

a. Uji Normalitas

Menurut Ghozali (2013:160), uji normalitas bertujuan untuk menguji apakah dalam model regresi variabel pengganggu atau residual memiliki distribusi normal. Cara untuk melihat normalitas residual adalah dengan melihat grafik histogram yang dibandingkan antara data observasi dengan distribusi yang mendekati distribusi normal. Distribusi normal akan membentuk satu garis lurus diagonal, dan ploting data residual akan dibandingkan dengan garis diagonal.

b. Grafik histogram maupun grafik normal plot memberikan pola distribusi yang menceng (skewness) ke kiri dan tidak normal. Sedangkan pada grafik normal plot terlihat titik-titik menyebar di sekitar garis diagonal, serta penyebarannya agak menjauh dari garis diagonal. Uji statistik lain yang dapat digunakan untuk menguji normalitas residual adalah uji statistik non-parametrik Kolmogorov-Smirnov (K-S).

c. Uji Multikolinieritas

Menurut Ghozali (2013:105), uji multikolinieritas bertujuan untuk menguji apakah pada model regresi ditemukan adanya korelasi antar variabel independen. Pada model regresi yang baik seharusnya tidak terjadi korelasi antar variabel independen. Pengujian multikolinieritas dilakukan dengan melihat VIF (Variance Inflation Factor) antar variabel independen. Nilai cut off yang dipakai untuk menunjukkan adanya multikolinieritas adalah nilai tolerance $\leq 0,10$ atau sama dengan nilai VIF $\geq 10$. Tolerance mengukur variabilitas variabel independen yang terpilih yang tidak dijelaskan oleh varibel independen lainnya. Nilai tolerance yang rendah sama dengan nilai VIF tinggi (karena VIF $=1$ /Tolerance).

d. Uji Autokolerasi

Menurut Ghozali (2013:110), uji autokolerasi bertujuan untuk menguji apakah dalam suatu model regresi ada korelasi antara kesalahan pengganggu pada periode t dengan kesalahan pada periode t-1 (sebelumnya). Jika terjadi korelasi, maka dinamakan ada problem autokorelasi. Autokorelasi muncul karena observasi yang berurutan sepanjang waktu berkaitan satu sama lainnya. Masalah ini timbul karena residual (kesalahan pengganggu) tidak bebas dari satu observasi ke observasi lainnya.

e. Uji Heteroskedastisitas

Menurut Ghozali (2013:139), uji heteroskedastisitas bertujuan untuk menguji apakah dalam model regresi terjadi ketidaksamaan variance antar satu pengamatan ke pengamatan lainnya. Model regresi yang baik adalah terjadi homoskedastisitas atau tidak terjadi heteroskedastisitas. Uji heteroskedastisitas dilakukan dengan melihat grafik plot antara nilai prediksi variabel terikat (dependen) yaitu ZPRED (Standardized Predicted Values) merupakan nilai-nilai prediksi yang terstandarisasi dengan residualnya SRESID (studentized residuals) merupakan residual student. Deteksi ada tidaknya heteroskedastisitas dapat dilakukan dengan melihat ada tidaknya pola tertentu pada grafik scatterplot antara SRESID dan ZPRED dimana sumbu Y adalah Y yang telah diprediksi, dan sumbu X adalah residual. Dasar analisis sebagai berikut : 
1. Jika ada pola tertentu, seperti titik-titik yang ada membentuk pola tertentu yang teratur (bergelombang, melebar kemudian menyempit), maka mengindikasikan telah terjadi heteroskedastisitas.

2. Jika tidak ada pola yang jelas, serta titik-titik menyebar di atas dan di bawah angka 0 pada sumbu Y, maka tidak terjadi heteroskedastisitas.

Koefisien Determinasi $\left(\mathrm{R}^{2}\right)$

Menurut Ghozali (2013:97), identifikasi koefisien determinasi ditujukan untuk mengukur seberapa jauh kemampuan model dalam menerangkan variabel terikat. Nilai koefisien determinasi $\left(\mathrm{R}^{2}\right)$ adalah antara nol dan satu. Kriteria penilaiannya adalah sebagai berikut :

1 Jika koefisien determinasi $\left(\mathrm{R}^{2}\right)$ semakin besar atau mendekati 1, maka dapat dikatakan bahwa kemampuan variabel bebas $(\mathrm{X})$ adalah besar terhadap variabel terikat $(\mathrm{Y})$. Hal ini berarti model yang digunakan semakin kuat untuk menerangkan pengaruh variabel bebas yang diteliti dengan variabel terikat.

2 Jika koefisien determinasi $\left(\mathrm{R}^{2}\right)$ semakin kecil atau mendekati 0 maka dapat dikatakan bahwa kemampuan variabel bebas $(\mathrm{X})$ terhadap variabel terikat $(\mathrm{Y})$ semakin kecil. Hal ini berarti model yang digunakan tidak cukup kuat menjelaskan pengaruh variabel bebas yang diteliti dengan variabel terikat.

Uji F

Uji serempak atau uji $-\mathrm{F}$ ini bertujuan untuk melihat sejauhmana pengaruh perputaran kas, perputaran piutang dan likuiditas secara bersama-sama mempengaruhi terhadap profitabilitas terhadap perusahaan property dan real estate yang terdaftar di BEI periode 2012-2015.

Uji t

Uji t ini bertujuan untuk melihat atau untuk mengetahui sejauhmana pengaruh sejauhmana pengaruh perputaran kas, perputaran piutang dan likuiditas secara parsial mempengaruhi terhadap profitabilitas terhadap perusahaan property dan real estate yang terdaftar di BEI periode 2012-2015.

\section{HASIL PENELITIAN DAN PEMBAHASAN}

\section{Hasil Penelitian}

\section{Uji Asumsi Klasik}

a. $\quad$ Uji Normalitas

Uji Normalitas bertujuan untuk mengetahui dalam model regresi, variabel penganggu atau residual. Uji normalitas digunakan untuk menguji apakah data berdistribusi dengan normal atau tidak yaitu melalui analisis :

1. Analisis Grafik

Salah satu cara untuk melihat normalitas residual adalah dengan melihat grafik histogram dengan melakukan perbandingan antara data observasi dengan distribusi yang mendekati distribusi normal. Distribusi normal akan membentuk suatu garis lurus diagonal dan ploting data residual akan dibandingkan dengan garis diagonal. Grafik hasil penelitian diperoleh sebagai berikut :

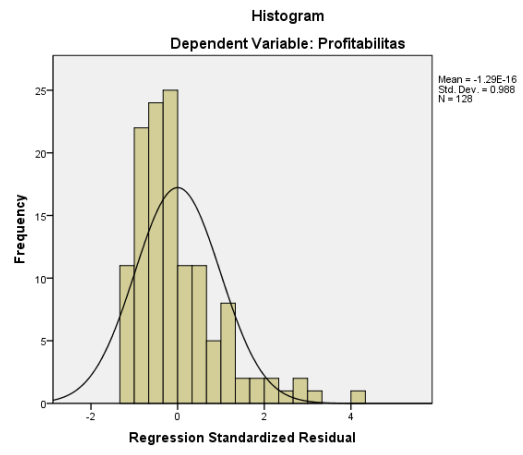

Gambar 2. Hasil Uji Asumsi Klasik Normalitas - Histogram (Sebelum Transformasi Data) 
Hasil grafik histogram menunjukkan adanya gambaran pola data yang kurang baik yang dapat dilihat dengan tampilan pola data pada gambar 3 menunjukkan tidak mengikuti garis ketentuan kurva berbentuk lonceng. Dengan demikian maka hasil ini juga tidak memenuhi syarat karena data tidak berdistribusi normal.

Normal P-P Plot of Regression Standardized Residual

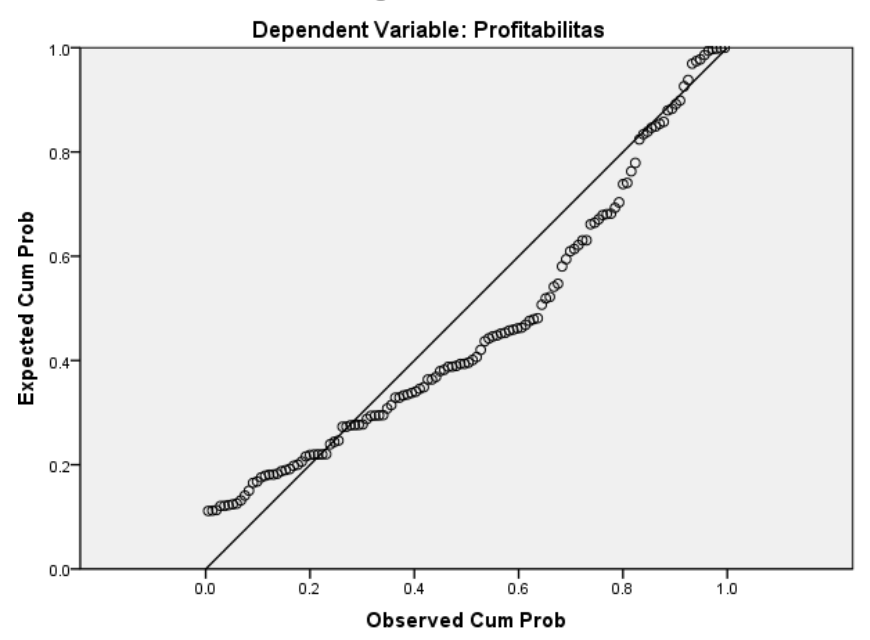

\section{Gambar 3. Hasil Uji Asumsi Klasik Normalitas - Probability Plot (Sebelum Transformasi Data)}

Hasil uji normality probability plot ini menunjukkan adanya pola data yang melenceng dari ketentuan yaitu pola data / titik-titik tidak menyebar di sekitar garis diagonal melainkan titik-titik saling berhimpit disekitar garis digonal seperti ditunjukkan pada gambar di atas. Dengan demikian maka hasil ini tidak memenuhi syarat karena data tidak berdistribusi normal. Untuk mengatasi agar kedua hasil uji normalitas dapat berdistribusi dengan normal maka dilakukan transformasi data dengan menggunakan Ln.

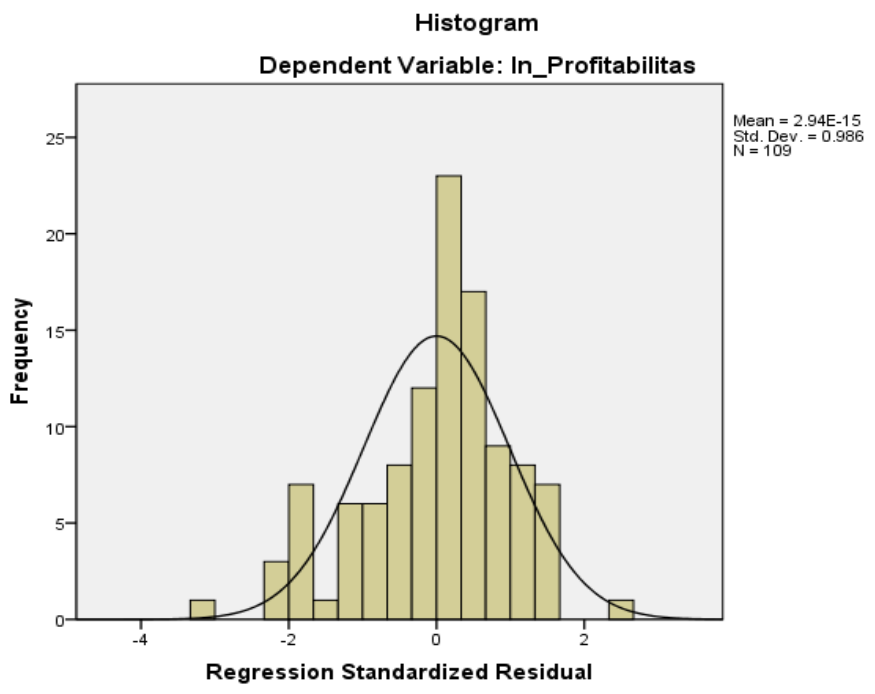

\section{Gambar 4. Hasil Uji Asumsi Klasik Normalitas - Histogram (Setelah Transformasi Data)}

Berdasarkan tampilan gambar 4. di atas terlihat bahwa grafik histogram menunjukkan bahwa kurva dependent dan regression standarized residual membentuk gambar seperti lonceng sehingga terlihat bahwa residual dihasilkan berdistribusi secara normal dan memenuhi asumsi normalitas dari data yang telah ditransformasikan layak diterima. 


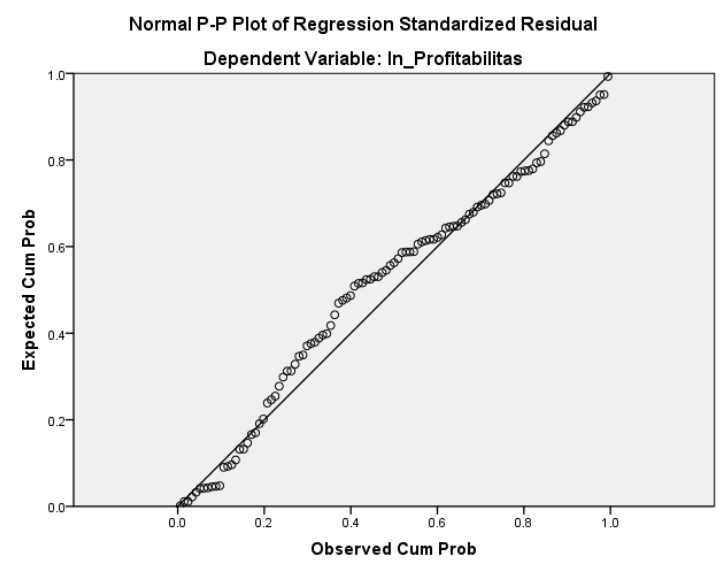

Gambar 5. Hasil Uji Asumsi Klasik Normalitas - Probability Plot (Setelah Transformasi Data)

Berdasarkan tampilan gambar 5. di atas terlihat bahwa grafik normality probability plot menunjukkan bahwa titik-titik menyebar di sekitar garis diagonal sehingga memenuhi asumsi normalitas dari data yang telah ditransformasikan layak diterima.

\section{Analisis Statistik}

Pada penelitian ini, uji statistik yang digunakan adalah dengan menggunakan metode Kolmogorov Smirnov (K-S) sebagai pedoman pengambilan keputusan mengenai data-data mendekati atau merupakan distribusi normal yang dapat dilihat dari :

- $\quad$ Nilai signifikansi atau probabilitas $<0,05$ maka distribusi data adalah tidak normal.

- $\quad$ Nilai signifikansi atau probabilitas $>0,05$ maka distribusi data adalah normal.

Hasil uji normalitas dengan menggunakan test non parametik Kolomogorov Smirnov sebelum data transformasi adalah terlihat pada tabel di bawah ini :

Tabel 2.Hasil Uji Asumsi Klasik Normalitas - Kolmogorov Smirnov (Sebelum Transformasi Data)

One-Sample Kolmogorov-Smirnov Test

\begin{tabular}{|ll|r|}
\hline & & $\begin{array}{c}\text { Unstandardiz } \\
\text { ed Residual }\end{array}$ \\
\hline N & Mean & 128 \\
Most Extreme Differences & Std. Deviation & .0000000 \\
& Absolute & 57.67764323 \\
& Positive & .160 \\
Kolmogorov-Smirnov Z & Negative & .160 \\
Asymp. Sig. (2-tailed) & & -.109 \\
\end{tabular}

a. Test distribution is Normal.

b. Calculated from data.

Berdasarkan tabel 2 , hasil uji Kolmogorov-Smirnov Z dan Asymp. Sig. (2-tailed) yang digunakan pada penelitian ini adalah data sebelum data ditransformasi (Ln) yaitu sebesar 1,589 dan 0,03. Data One Sample Kolmogorov-Smirnov menunjukkan nilai Kolmogorov-Smirnov Z sudah memenuhi kriteria dimana sig. lebih besar dari 0,05 akan tetapi Asymp. Sig. (2-tailed) < nilai probabilitas $(0,05)$ maka data yang telah berdistribusi bersifat tidak normal. Dengan demikian, data pada penelitian ini berdistribusi tidak normal dan melalukan pengujian ulang 
dengan transformasi data atau Ln karena memiliki nilai signifikan $<0,05$. Oleh karena itu, perlu dilakukan transformasi data agar data penelitian ini menjadi normal.

Hasil uji normalitas dengan menggunakan test non parametik Kolmogorov Smirnov setelah transformasi data adalah terlihat pada tabel 3 di bawah ini :

Tabel 3. Hasil Uji Asumsi Klasik Normalitas - Kolmogorov Smirnov (Setelah Transformasi Data)

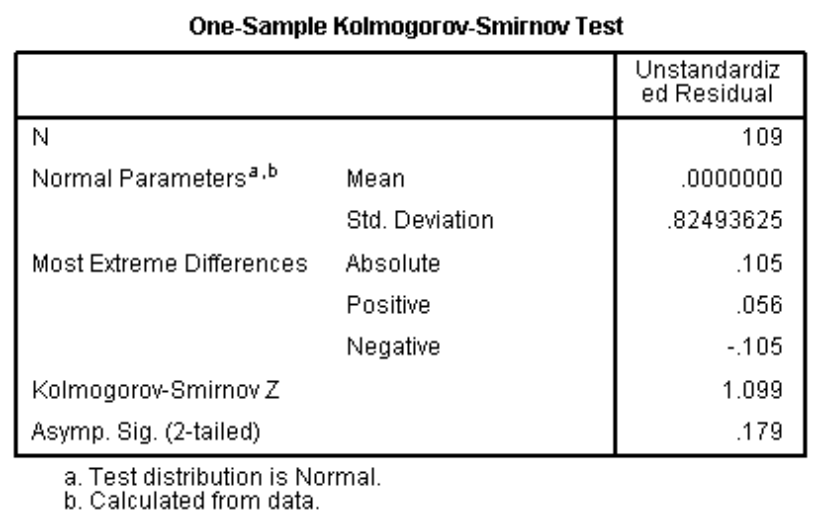

Berdasarkan tabel 3, hasil uji Kolmogorov-Smirnov Z dan Asymp. Sig. (2-tailed) yang digunakan pada penelitian ini adalah data setelah dilakukan transformasi (Ln) yaitu sebesar 1,140 dan 0,148. Data One Sample Kolmogorov-Smirnov menunjukkan nilai Kolmogorov-Smirnov Z dan Asymp. Sig. (2-tailed) > nilai probabilitas $(0,05)$ yaitu $0,179>0,05$ maka data telah berdistribusi bersifat normal. Dengan demikian, data pada penelitian ini berdistribusi normal.

b.. Uji Multikolinieritas

Uji multikolinieritas bertujuan untuk menguji apakah model regresi ditemukan adanya korelasi antar variabel bebas (independen). Pengujian multikolinieritas dilakukan dengan melihat VIF antar variabel independen. Berikut adalah hasil uji multikolinieritas variabel sebelum transformasi data adalah terlihat pada tabel 4.3 di bawah ini :

\section{Tabel 4.Hasil Uji Multikolinieritas}

\begin{tabular}{|c|c|c|c|c|c|c|c|c|}
\hline \multicolumn{9}{|c|}{ Coefficients $^{a}$} \\
\hline \multirow{2}{*}{\multicolumn{2}{|c|}{ Model }} & \multicolumn{2}{|c|}{ Unstandardized Coefficients } & \multirow{2}{*}{$\begin{array}{c}\begin{array}{c}\text { Standardized } \\
\text { Coefficients }\end{array} \\
\text { Beta }\end{array}$} & \multirow[b]{2}{*}{$t$} & \multirow[b]{2}{*}{ Sig. } & \multicolumn{2}{|c|}{ Collinearity Statistics } \\
\hline & & $\mathrm{B}$ & Std. Error & & & & Tolerance & VIF \\
\hline \multirow[t]{4}{*}{1} & (Constant) & -6.051 & 2.742 & & -2.207 & .030 & & \\
\hline & In_Perputaran_Kas & .443 & .127 & .489 & 3.482 & .001 & .383 & 2.612 \\
\hline & In_Perputaran_Piutang & .152 & .059 & .237 & 2.585 & .011 & .895 & 1.117 \\
\hline & In_Likuiditas & .711 & .273 & .359 & 2.607 & .010 & .399 & 2.508 \\
\hline
\end{tabular}

a. Dependent Variable: In_Profitabilitas

Berdasarkan tabel 4di atas menunjukkan hasil perhitungan nilai tolerance keempat variabel independen yaitu perputaran kas, perputaran piutang, arus kas operasi dan likuiditas memiliki nilai tolerance lebih > 0,1 dan nilai VIF yang diperoleh untuk setiap variabel $<10$ maka model penelitian ini dapat dikatakan bebas dari multikolinieritas.

\section{c. Uji Autokorelasi}

Uji ini bertujuan menguji apakah dalam model regresi linear ada korelasi antara kesalahan pengganggu pada periode $\mathrm{t}$ dengan kesalahan pengganggu pada periode t-1 (sebelumnya). Model regresi yang baik adalah regresi yang bebas dari autokorelasi. Salah satu ukuran dalam menentukan ada tidaknya masalah autokorelasi dengan uji Run Test. Hasil uji autokorelasi variabel sebelum transformasi data adalah terlihat pada tabel 4.4 di bawah ini : 
Tabel 5. Hasil Uji Autokorelasi - Run Test

\begin{tabular}{|l|r|}
\hline \multicolumn{2}{|c|}{ Runs Test } \\
\hline & $\begin{array}{c}\text { Unstandardiz } \\
\text { ed Residual }\end{array}$ \\
\hline Test Value $^{\mathrm{a}}$ & .13210 \\
Cases $<$ Test Value $^{\mid}$ & 54 \\
Cases $>=$ Test Value & 55 \\
Total Cases & 109 \\
Number of Runs & 42 \\
Z & -2.598 \\
Asymp. Sig. (2-tailed) & .009 \\
\hline
\end{tabular}

Berdasarkan tabel 5 di atas menunjukkan hasil pengolahan data diperoleh nilai statistik nilai Test Value adalah 0,13210 dengan probabilitas sebesar 0,09>0,05 yang berarti bahwa residual random atau tidak terdapat masalah autokorelasi dalam penelitian ini.

d. Uji Heteroskedastisitas

Uji heteroskedastisitas bertujuan untuk menguji apakah dalam model regresi terjadi ketidaksamaan variance dari residual satu pengamatan ke pengamatan yang lain.

Berikut adalah hasil uji heteroskedastisitas variabel yang digunakan dalam penelitian.

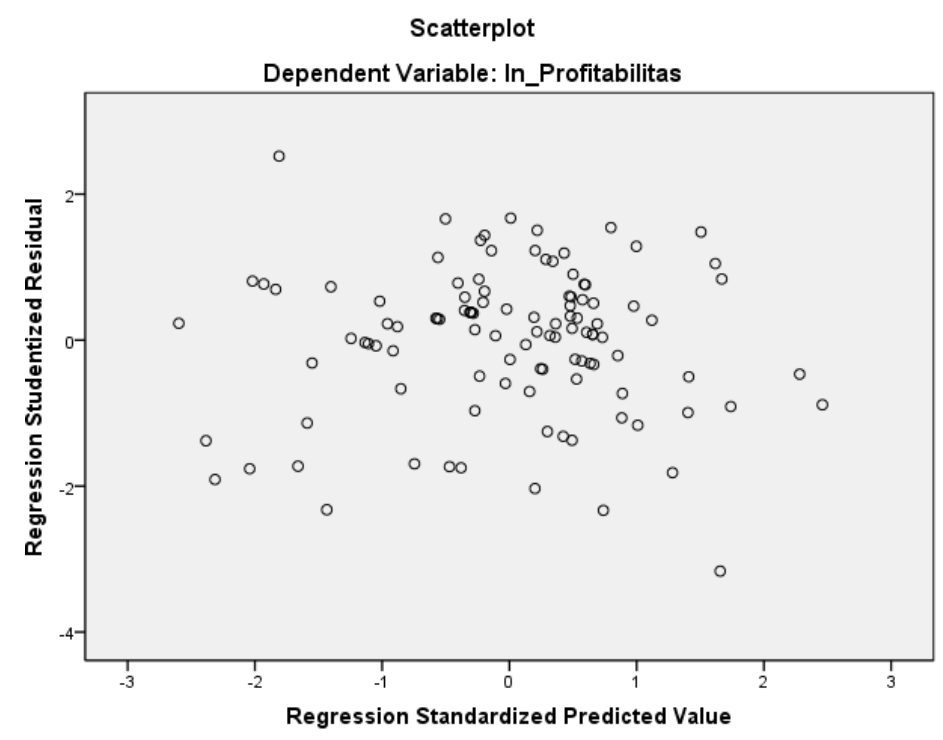

Gambar 6.Hasil Uji Heteroskedastisitas -Scatterplot

Dari gambar di atas memperlihatkan bahwa titik-titik menyebar secara acak di atas maupun di bawah angka 0 dan pada sumbu Y. Dengan demikian dapat disimpulkan bahwa tidak terjadi heteroskedastisitas pada model sehingga model penelitian ini layak dipakai.

\section{Koefisien Determinasi}

Nilai koefisien determinasi digunakan untuk mengukur seberapa besar pengaruh perputaran kas, perputaran piutang, arus kas operasi dan likuiditas terhadap profitabilitas pada perusahaan property dan real estate di BEI. Hasil perhitungan dapat dilihat pada tabel 6. 


\section{Tabel 6. Hasil Uji Koefisien Determinasi}

Model Summary

\begin{tabular}{|l|l|l|r|r|r|}
\hline Model & $\mathrm{R}$ & $\mathrm{R}$ Square & $\begin{array}{c}\text { Adjusted R } \\
\text { Square }\end{array}$ & $\begin{array}{c}\text { Std. Error of } \\
\text { the Estimate }\end{array}$ & $\begin{array}{c}\text { Durbin- } \\
\text { Watson }\end{array}$ \\
\hline 1 & $.456^{\mathrm{a}}$ & .208 & .185 & .83664 & 1.482 \\
\hline
\end{tabular}

a. Predictors: (Constant), In_Likuiditas, In_Perputaran_Piutang,

In Perputaran Kas

b. Dependent Variable: In_Profitabilitas

Pada tabel 6 menunjukkan bahwa hubungan yang terjadi antara perputaran kas, perputaran piutang, dan likuiditas sebagai variabel independen dan profitabilitas sebagai variabel dependen menunjukkan hubungan yang cukup tinggi. Hal ini terlihat dari nilai $R$ Square menunjukkan sebesar 0,185 atau sekitar $18,5 \%$ yang berarti variabel independen dapat menjelaskan $18,5 \%$ variabel profitabilitas sedangkan sisanya sebesar $81,5 \%$ merupakan pengaruh dari variabel bebas lain yang tidak diteliti dalam penelitian ini.

\section{Uji F}

Uji ini bertujuan untuk menunjukkan bagaimana pengaruh variabel independen terhadap variabel dependen secara bersama-sama. Uji ini bertujuan untuk menunjukkan bagaimana pengaruh variabel independen terhadap variabel dependen secara bersama-sama.

\section{Tabel 7. Hasil Uji F}

\begin{tabular}{|c|c|c|c|c|c|c|}
\hline \multicolumn{7}{|c|}{ ANOVA ${ }^{b}$} \\
\hline \multicolumn{2}{|c|}{ Model } & $\begin{array}{c}\text { Sum of } \\
\text { Squares }\end{array}$ & df & Mean Square & $\mathrm{F}$ & Sig. \\
\hline \multirow[t]{3}{*}{1} & Regression & 19.270 & 3 & 6.423 & 9.177 & $.000^{a}$ \\
\hline & Residual & 73.496 & 105 & .700 & & \\
\hline & Total & 92.766 & 108 & & & \\
\hline
\end{tabular}

b. Dependent Variable: In_Profitabilitas

Berdasarkan hasil uji $\mathrm{F}$ pada tabel 4.8 diperoleh nilai $\mathrm{F}_{\text {tabel }}$ untuk df pembilang $\left(\mathrm{N}_{1}\right)=\mathrm{k}-1=5-1=4$ dan df penyebut $\left(\mathrm{N}_{2}\right)=\mathrm{n}-\mathrm{k}=128-5=123$, maka diperoleh nilai $\mathrm{F}_{\text {tabel }}=2,45$. Nilai $\mathrm{F}_{\text {hitung }}$ pada uji ANOVA atau $\mathrm{F}$ test, yaitu nilai $F_{\text {hitung }}>F_{\text {tabel }}$ dengan nilai 5,132 $>2,45$ dengan nilai signifikan 0,000 0,05 maka dapat dikatakan bahwa perputaran kas, perputaran piutang, dan likuiditas berpengaruh terhadap profitabilitas pada perusahaan property dan real estate yang terdaftar di BEI.

\section{Uji t}

Tujuan dilakukannya uji t (parsial) ini yaitu untuk melihat seberapa jauh pengaruh satu variabel independen terhadap variabel dependen secara individual.

Berdasarkan hasil uji t pada tabel IV.14 diperoleh nilai $\mathrm{t}_{\text {tabel }}$ untuk $\mathrm{df}=\mathrm{n}-\mathrm{k}=128-5=123$ dan signifikansi 0,05 pada uji signifikansi 2 arah adalah sebesar 1,97944. Dengan demikian hasil dari uji t dapat dijelaskan sebagai berikut.

1. Pada variabel perputaran kas nilai $\mathrm{t}_{\text {hitung }}$ sebesar 3.482 dan signifikan 0,01 dengan menguraikan $\mathrm{t}_{\text {tabel }}$ diperoleh nilai 1,97944 maka $t_{\text {hitung }}<\mathrm{t}_{\text {tabel }}(3.482>1.97944)$ dan nilai signifikan $(0,01>0,05)$ maka $\mathrm{H}_{0}$ diterima yaitu perputaran kas berpengaruh signifikan terhadap profitabilitas.

2. Pada variabel perputaran piutang nilai $t_{\text {hitung }}$ sebesar 2.585 dan signifikan 0.01 dengan menguraikan $t_{\text {tabel }}$

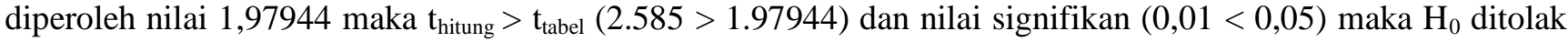
yaitu perputaran piutang berpengaruh signifikan terhadap profitabilitas.

3. Pada variabel likuiditas nilai $t_{\text {hitung }}$ sebesar 2.607 dan signifikan 0,010 dengan menguraikan $t_{\text {tabel }}$ diperoleh nilai 1,97944 maka $t_{\text {hitung }}<\mathrm{t}_{\text {tabel }}(2.607<1,97944)$ dan nilai signifikan $(0,010<0,05)$ maka $\mathrm{H}_{0}$ diterima yaitu likuiditas berpengaruh signifikan terhadap profitabilitas. 


\section{Pengujian Hipotesis}

a. Pengaruh Perputaran Kas Terhadap Profitabilitas

Berdasarkan hasil pengujian secara parsial (Uji t) diperoleh $\mathrm{t}_{\text {hitung }}<\mathrm{t}_{\text {tabel }}(3,482<1,97944)$ maka $\mathrm{H}_{0}$ diterima dan $\mathrm{H}_{1}$ ditolak pada $\alpha=5 \%$ dengan nilai signifikan $0,01>0,05$. Dengan demikian perputaran kas berpengaruh signifikan terhadap profitabilitas pada perusahaan property dan real estate yang terdaftar di BEI periode 2012-2015. Hasil ini sejalan dengan penelitian sebelumnya yang dilakukan I Putu Gede Narayana (2013) yang menyatakan bahwa perputaran kas berpengaruh secara parsial terhadap profitabilitas.

b. Pengaruh Perputaran Piutang Terhadap Profitabilitas

Berdasarkan hasil pengujian secara parsial (Uji t) diperoleh $t_{\text {hitung }}>t_{\text {tabel }}(2.585>1,97944)$ maka $\mathrm{H}_{0}$ ditolak dan $\mathrm{H}_{1}$ diterima pada $\alpha=5 \%$ dengan nilai signifikan $0,01<0,05$. Dengan demikian perputaran piutang berpengaruh signifikan terhadap profitabilitas pada perusahaan property dan real estate yang terdaftar di BEI periode 2012-2015.

Hasil ini sejalan dengan penelitian sebelumnya yang dilakukan Luh Komang Suarnami, I Wayan Suwendra, Wayan Cipta (2014) yang menyatakan bahwa perputaran piutang berpengaruh terhadap profitabilitas.

c. Pengaruh Likuiditas Terhadap Profitabilitas

Berdasarkan hasil pengujian secara parsial (Uji t) diperoleh $\mathrm{t}_{\text {hitung }}<\mathrm{t}_{\text {tabel }}\left(2.607<1,97944\right.$ ) maka $\mathrm{H}_{0}$ diterima dan $\mathrm{H}_{1}$ ditolak pada $\alpha=5 \%$ dengan nilai signifikan $0,010<0,05$. Dengan demikian likuiditas tidak berpengaruh signifikan terhadap profitabilitas pada perusahaan property dan real estate yang terdaftar di BEI periode 2012-2015.

Hasil ini tidak sejalan dengan penelitian sebelumnya yang dilakukan Made Windi Ariani, Putu Agus Ardiana (2015) yang menyatakan bahwa likuiditas berpengaruh terhadap profitabilitas.

\section{Kesimpulan}

\section{PENUTUP}

Berdasarkan hasil pengujian, penelitian dan pembahasan yang telah dilakukan pada penelitian, maka peneliti akan menyimpulkan beberapa kesimpulan yaitu sebagai berikut :

1. Perputaran kas berpengaruh signifikan secara parsial terhadap profitabilitas pada perusahaan property dan real estate yang terdaftar di BEI periode 2012-2015.

2. Perputaran piutang berpengaruh signifikan secara parsial terhadap profitabilitas pada perusahaan property dan real estate yang terdaftar di BEI periode 2012-2015.

3. Likuditas berpengaruh signifikan secara parsial terhadap profitabilitas pada perusahaan property dan real estate yang terdaftar di BEI periode 2012-2015

4. Perputaran Kas, Perputaran Piutang, dan Likuiditas berpengaruh secara simultan terhadap profitabilitas pada perusahaan property dan real estate yang terdaftar di BEI periode 2012-2015, dengan nilai $R$ Square menjelaskan pengaruh variabel independen terhadap variabel dependen sebesar 18,5\% dan sisanya sebesar $81,5 \%$ dipengaruhi oleh faktor-faktor lain diluar variabel.

\section{Saran}

Saran-saran yang dapat dikemukakan peneliti berkaitan dengan hasil penelitian ini antara lain :

1. Bagi peneliti lain agar sampel penelitian menggunakan populasi yang lebih luas dan sampel yang lebih banyak sehingga hasil yang diperoleh lebih akurat dan tepat.

2. Bagi perusahaan agar manajemen tetap memperhatikan perputaran piutang dalam melaksanakan kegiatan operasionalnya karena variabel ini dapat mempengaruhi besarnya profitabilitas sebagai gambaran keuangan perusahaan.

3. Bagi Investor yang ingin melakukan investasi hendaknya melakukan penelitian lebih lanjut mengenai kinerja perusahaan yang menyangkut perputaran kas, perputaran piutang, arus kas operasi dan likuiditas. Investor juga perlu mengantisipasi faktor-faktor lain yang berpengaruh terhadap profitabilitas perusahaan. 


\section{DAFTAR PUSTAKA}

Ariani, Made Windi dan Putu Agus Ardiana. 2015. Pengaruh Kecukupan Modal, Tingkat Efisiensi, Risiko Kredit dan Likuiditas Pada Profitabilitas LPD Kabupaten Badung. Jurnal Ekonomi dan Bisnis Universitas Udayana.

Brigham, Eugene \& Joel F. Houston. 2010. Dasar - dasar Manajemen Keuangan. Edisi 11. Jakarta : Salemba Empat.

Effendi, Sofian dan Tukiran. 2012. Metode Penelitian Survei. Cetakan Ketiga Puluh. Edisi Revisi. Jakarta : LP3ES.

Ginting, Suriani. 2012. Analisis Faktor-faktor Yang Mempengaruhi Return Saham Pada Perusahaan Manufaktur Yang Terdaftar DI Bursa Efek Indonesia. Jurnal Wira Ekonomi Mikroskil, Vol. 3.

Ghozali, Imam. 2013. Aplikasi Analisis Multivariate dengan Program IBM SPSS 19. Edisi 5, Semarang : Universitas Diponegoro.

Harahap, Sofyan Syafri. 2007. Teori Akuntansi. Edisi Revisi ke-9. Jakarta : PT Raja Grafindo Persada.

Husnan, Suad dan Enny Pudjiastuti. 2012. Dasar-dasar Manajemen Keuangan. Edisi Keenam. Yogyakarta : UPP STIM YKPN.

Hery. 2013. Akuntansi Keuangan Menengah. Cetakan Pertama. Yogyakarta : CAPS (Center of Academic Publishing Service). 2014. Analisis Laporan Keuangan. Cetakan Kedua. Edisi 1. Jakarta : PT Bumi Aksara.

Horne, James C. Van dan John M. Wachowicz. 2014. Fundamentals of Financial Prinsip-prinsip Manajemen Keuangan. Buku 1 Edisi 13. Jakarta : Salemba Empat.

Harahap, Sofyan Syafri. 2015. Analisis Kritis atas Laporan Keuangan. Cetakan Kedua Belas. Edisi 1. Jakarta : PT Raja Grafindo Persada.

Jumingan.2008. Analisis Laporan Keuangan. Cetakan Kedua. Jakarta : PT Bumi Aksara.

Keown, Arthur. et.al. 2008. Prinsip dan Penerapan Manajemen Keuangan. Edisi Kesepuluh. Jakarta : PT Macanan Jaya Cemerlang.

Kasmir. 2012. Analisis Laporan Keuangan. Cetakan Kelima. Jakarta : PT Grafindo Persada.

Munawir. 2014. Analisa Laporan Keuangan. Cetakan Ketiga Belas. Edisi Keempat. Yogyakarta : Liberty Yogyakarta.

Munadhiroh, Attin dan Nurchayati. 2015. Pengaruh Arus Kas Operasi dan Likuiditas Terhadap Profitabilitas (Studi Empiris Pada Perusahaan Property dan Real Estate Yang Terdaftar di BEI). Jurnal Ilmiah UNTAG Semarang, vol 4, no 3.

Narayana, I Putu Gede. 2013. Pengaruh Perputaran Kas, Loan to Deposit Ratio, Tingkat Permodalan dan Leverage Terhadap Profitabilitas Bank Perkreditan Rakyat (BPR) Se-Kota Denpasar Periode 2009-2011. Jurnal Ekonomi Universitas Udayana.

Riyanto, Bambang. 2008. Dasar-dasar Pembelanjaan Perusahaan. Edisi Keempat. Yogyakarta : BPFE.

Subramanyam, K.R \& John Wild. 2010. Analisis Laporan Keuangan. Edisi Kesepuluh. Jakarta : Salemba Empat.

Syamsuddin, Lukman. 2011. Manajemen Keuangan Perusahaan. Cetakan Kesebelas. Edisi Baru. Jakarta : PT Rajagrafindo Persada.

Sudana, I Made. 2011. Manajemen Keuangan Perusahaan Teori dan Praktik. Jakarta : Erlangga.

Sugiyono. 2012. Metode Penelitian Bisnis. Cetakan Ke - 16. Bandung : Alfabeta.

Sanusi, Anwar. 2014. Metodologi Penelitian Bisnis. Cetakan Keempat. Jakarta : Salemba Empat.

Suarnami, Luh Komang. et.al. 2014. Pengaruh Perputaran Piutang dan Periode Pengumpulan Piutang Terhadap Profitabilitas Pada Perusahaan Pembiayaan. Jurnal Manajemen Universitas Pendidikan Ganesha, Vol. 2.

Sartono, Agus. 2015. Manajemen Keuangan Teori dan Aplikasi. Edisi Keempat. Yogyakarta : BPFE. 